\title{
EU Policies Driving Entrepreneurial Competences-Reflections from the Case of EntreComp
}

\author{
Jaana Seikkula-Leino ${ }^{1,2, * \mathbb{C}}$, Maria Salomaa ${ }^{1,3}{ }^{\mathbb{C}}$, Svanborg Rannveig Jónsdóttir ${ }^{4}$, Elin McCallum ${ }^{5}$ \\ and Hazel Israel ${ }^{5}$ \\ 1 RDI and Business Operations, Tampere University of Applied Sciences, 33520 Tampere, Finland; \\ maria.e.salomaa@gmail.com \\ 2 Department of Education, Faculty of Human Sciences, Mid Sweden University, 85230 Sundsvall, Sweden \\ International Business School, University of Lincoln, Lincoln LN6 7TS, UK \\ 4 School of Education, University of Iceland, 102 Reykjavík, Iceland; svanjons@hi.is \\ 5 Bantani Education, 3080 Tervuren, Belgium; elin@bantani.com (E.M.); hazel@bantani.com (H.I.) \\ * Correspondence: jaana.seikkula-leino@tuni.fi
}

Citation: Seikkula-Leino, J.; Salomaa, M.; Jónsdóttir, S.R.; McCallum, E.; Israel, H. EU Policies Driving Entrepreneurial

Competences-Reflections from the Case of EntreComp. Sustainability 2021, 13, 8178. https://doi.org/ $10.3390 /$ su13158178

Academic Editor: Andrea Pérez

Received: 25 May 2021

Accepted: 18 June 2021

Published: 22 July 2021

Publisher's Note: MDPI stays neutral with regard to jurisdictional claims in published maps and institutional affiliations.

Copyright: (C) 2021 by the authors. Licensee MDPI, Basel, Switzerland. This article is an open access article distributed under the terms and conditions of the Creative Commons Attribution (CC BY) license (https:// creativecommons.org/licenses/by/ $4.0 /)$.

\begin{abstract}
The United Nations' Sustainable Development Goals promote entrepreneurial competences as a means of supporting young people to innovate, start businesses, and create jobs. Furthermore, the European Union considers entrepreneurial skills to be essential in creating welfare and economic sustainability. Empowering individuals with entrepreneurship education, an entrepreneurial mindset and behaviors, are tools to develop human capital. This article explores how European policies can drive development of entrepreneurial competences by examining the case of the European Framework for Entrepreneurial Competences (EntreComp) and its integration into education and training development in different countries. With this research, we contribute education development from the practical point of view by analyzing how a cross section of actors, using EntreComp as a European framework for entrepreneurial competences, see that entrepreneurial learning has been realized and could be further supported in transnational education contexts. We will also expand the theoretical discussion of entrepreneurship education from the perspective of education sciences, as we have not previously obtained clarifying results or conclusions on how, for example, the educational change related to the development of entrepreneurship education should be implemented. The research data was collected through a case study, for which an online survey including both quantitative and qualitative approaches was conducted in 2020. Responses from 348 respondents from 47 countries were analyzed through an extended model for learning originally conceptualized by Shulman and Shulman (2004). The findings suggest that EntreComp has been widely recognized as a critical driver of competence in entrepreneurial education. However, a lack of shared vision and development of practice in the use of EntreComp can hinder the effective implementation of the framework. Thus, further support and guidance are needed in promoting the learning process of policymakers, educators, trainers, and other stakeholders, on both micro- and macro-level education design, to support successful adoption and adaptation of the policy-driven frameworks.
\end{abstract}

Keywords: entrepreneurship education; entrepreneurial competences; learning community; EntreComp; EU policy

\section{Introduction}

Sustainable Development Goals (SDGs), adopted by the United Nations [1] Member States in 2015, have increasingly focused on entrepreneurial learning interventions to support ambition in young people to start their own businesses and generate their own employment opportunities (SDG4.4 and SDG8.3). Furthermore, the European Union (EU) considers entrepreneurial skills to be an essential factor in creating social and economic sustainability. Entrepreneurship education (EE) seeks to empower individuals with sufficient formal education and training to support entrepreneurial behavior and thinking. 
According to European policy documents [2], we need skills and competences that support personal development, social inclusion, active citizenship, and employment. The key competences believed to enhance human capital, welfare, and competitiveness include literacy, numeracy, science, and foreign languages as well as transversal skills, e.g., digital competences, entrepreneurship, critical thinking, and problem solving [3]. Entrepreneurship education can cultivate such competences throughout life in different contexts and for different purposes, such as using these competences to create entrepreneurial actions impacting on sustainable development goals (e.g., [1,4], in particular SDG4.7). Furthermore, entrepreneurial culture enables, e.g., SMEs to turn environmental challenges into opportunities [5].

The European Entrepreneurship Competence Framework (EntreComp) is one of the EU's responses to support common understanding and widespread integration of entrepreneurship, within and across education systems, promoting entrepreneurial learning towards social, cultural, or financial value creation. EntreComp is suggested as a tool for supporting development of the entrepreneurial capacities of European citizens and organizations by establishing a consistent reference point to support development of shared concepts of entrepreneurship competences, goal setting, and evaluation. Previous studies on EntreComp indicate that it is possible to build education programs on EntreComp [6-10] by using the framework as a basis for curricula development and learning activities. As Bacigalupo et al. [3] stress, the use of the framework is claimed to foster entrepreneurship as a transversal and holistic competence, applicable to diverse purposes and contexts. The framework can also be used to describe and differentiate outcomes and attainment in the assessment of entrepreneurial competences [3]. For example, in Finland EntreComp has been adapted into higher education teaching practices with good results. Recent empirical evidence indicates that the EntreComp competences are attributes of success aligned with the expectations of the future of working life, and are therefore meaningful for transforming education [11].

Although entrepreneurship education appears to be gaining ground [12], with widespread policy recognition of the need for educational reforms, educators and other education professionals have struggled to identify the content and methods with which to implement EE. It has also been acknowledged that educators' learning processes have been missing from education policy implementation [13]). However, consideration of educators' reflections and learning processes are a crucial feature of successful educational reforms, such as the implementation of the EU strategies and frameworks that form a vision for the future of education. Additionally, motivation for change, sufficient substance knowledge, and understanding of how to implement these reforms in practice are essential [14,15]. This is also supported by Kelchtermans' [16] claim that educators' sense of identity and their individual roles are key drivers of active engagement with educational review and renewal processes. Strengthening this, the Eurydice report [12] states that educators' attitudes and behaviors in EE may be even more important than substance knowledge.

Previous studies imply that the successful development of entrepreneurship education by engaging educators is a complex issue. In response, many scholars have introduced new approaches to widen the discussion using learning communities [17-21] and extending resource bases (e.g., society) for EE activities [20,22]. These approaches offer new possibilities for learners to gain experiences and insight through a participatory approach, which involves, e.g., policy-makers, representatives from private and public sectors, and parents [13]. To cultivate a supportive ecosystem for EE, teachers, educators, policy-makers and communities may need to collaboratively reconsider their values and assumptions about school and education [23,24]. As Perrotta [25] argues, educational cultures, policies, rationality, and emotional dimensions have high significance when adopting new approaches to education. This complexity is also highlighted in curriculum reform research: promoting an enterprising culture through curriculum reform requires meaningful, well-designed partnerships, securing wide participation of internal and external stakehold- 
ers [26]. Such partnerships need to take into account local curricula, specific characteristics of different communities, and a focus on practice-oriented reforms [23,26].

However, there can be a significant gap between policy document recommendations and the design and implementation of entrepreneurship education in practice. In this paper, we anticipate that the development of entrepreneurial competences, driven by EU policies, requires the engagement and involvement of the whole learning community, acting as co-creators in the policy implementation through practice-oriented reforms. This approach is also highlighted by the chosen case study of the EntreComp framework. Therefore, this study investigates how the EntreComp framework has been implemented in transnational education contexts, looking particularly at how EntreComp guides the creation of a future vision for integrating entrepreneurship education to educational practices. Empirical data was collected from educators to examine how it is implemented and understood in practice: how can the framework motivate educational change and reform? By addressing these issues, we highlight how a policy-driven entrepreneurial competence framework can provoke, support, and drive educational change in Europe, and describe what kind of activities might further strengthen entrepreneurial competences and the sustainability of education in practice. Our case study also opens up opportunities for further research. For example, Cohen et al. [27] argue the generalizability of such single experiments (e.g., case and pilot studies) can be further extended through replication or multiple experiment strategies, allowing single case studies to contribute to the development of a growing pool of data. In this context, we may consider case studies methodologically, both quantitative and qualitative, that we adapt for our purpose in studying the case of EntreComp.

A case study of the EntreComp360 project [28] allowed the gathering of a wide transnational data set. The project's main goal was to develop opportunities to connect the wider community and provide guidance and resources to support those who are inspired by, or are already using, EntreComp across lifelong learning. To achieve this, it was essential to obtain an overview of European entrepreneurship education and how EntreComp is, and might be, integrated into it. Therefore, the EntreComp online survey was issued in 2020 targeting policymakers, lifelong learning organizations, educators, and other stakeholders. A comparative approach reveals: what are the learning communities' key reflections and learning processes related to development of entrepreneurial competences? What is their vision for the future implementation of EntreComp? What is their motivation for change? How do they perceive and utilize EntreComp? Both quantitative and qualitative data were collected as part of the study. In total, there were 348 respondents from 47 countries. The country comparison is shown between the U.K., Finland, Spain, Germany, Italy, and Iceland to identify varying levels of integration of the framework in different national contexts.

The paper is structured as follows: firstly, we highlight the key points of the theoretical debate around EU policies driving entrepreneurship education and learning communities to create a framework for analysis by adapting the Shulman and Shulman framework [14]. Secondly, we present the case of EntreComp, methodological choices, and data collection methods. Thirdly, we summarize the key results from the survey. Fourthly, we summarize the results gained in terms of what gaps can be identified, and what leverage is needed to support coherent educational reform to promote entrepreneurial competencies across Europe. Finally, we conclude that a lack of shared vision, motivation, practices, and understanding of entrepreneurship education can hinder the effective implementation of the framework. We propose further research on the integration of individual and community learning processes into the designing of the policy tools.

\section{Literature Review}

\subsection{European Policies Driving Entrepreneurship Education}

Since 2003, there has been a concerted effort by the European Commission to drive entrepreneurship education forward. The inclusion of entrepreneurship as one of the eight European Key Competences in 2006 led to the agreement by all EU Member States to embed these key competences into their education and training systems; however, the 2016 
Eurydice study [12] demonstrated that the approach is fragmented and not mainstreamed for the entrepreneurship key competence. This visibility has increased since the launch of the Europe 2020 strategy through education and training focused policy documents culminating in the 2016 and 2020 Skills Agendas [2]. These reaffirmed the importance of the entrepreneurship key competence with three key work strands: improving the quality and relevance of skills formation; making skills and qualifications more visible and comparable; and advancing skills intelligence, documentation, and informed career choice. The 2020 European Skills Agenda is now setting the framework for policy and reform at EU and national levels, stressing the importance of developing an entrepreneurial mindset and giving all learners at least one entrepreneurial hands-on experience during compulsory education, as well as strengthening VET and STEM education through entrepreneurial work-based learning. The importance of transversal skills was reaffirmed by the European Council in the 2018 conclusions and emphasized within the European Pillar of Social Rights [29].

In constantly developing societies, in which technological solutions innovate at pace, and social and environmental challenges relentlessly evolve and emerge, versatile and action-orientated competences are indeed essential for taking part in and contributing to society. Education is the primary lever to develop human consciousness and mentally self-conscious individuals to secure long-term sustainability and ensure a sustainable future [30]. General education is expected to provide a broad and balanced range of knowledge and skills in modern societies. Creative thinking, social skills, and the capacity to solve relevant and meaningful problems, are considered to be fundamental competences in promoting sustainable societies [31]. Entrepreneurial education, also referred to as entrepreneurship education, offers a way to nurture such competences. Entrepreneurship education is integrative in nature, with applications across different knowledge areas and purposes [26,32]. The core pedagogy of entrepreneurship education has been analyzed as emancipatory pedagogy, aiming to give the student agency and freedom to develop creative, independent, and action competences $[23,32,33]$.

The purpose of EE is to educate students to take more responsibility for themselves and their learning; to achieve their goals, to become creative, active and critical citizens; to discover existing opportunities and create new ones; and to cope and thrive in a complicated society $[32,34]$. An essential aim is that students take an active role in the labor market, considering entrepreneurship as a natural career choice [15]. Entrepreneurial education involves developing behaviors, skills, and attributes, applied both individually and collectively, to help individuals and organizations of all kinds, to create, cope, enjoy, change, and innovate (e.g., [20]). It is worth emphasizing that academics have warned that EE should not be too simplistic or too focused on market or business creation in order to offer viable solutions to complex social, cultural, and economic issues [35,36].

Since this study explores how European policies can drive development of entrepreneurial competences by examining the case of the European Framework for Entrepreneurial Competences (EntreComp) and its integration into education and training development in different countries, we will next focus on the key elements of the EntreComp framework.

\subsection{EntreComp Framework Strengthening Entrepreneurial Competences}

The EntreComp framework is comprehensive and detailed, creating a construct of entrepreneurial competences that can be developed through entrepreneurial education. Its primary purposes are to create a common understanding of entrepreneurship as a key competence and to establish a common language for entrepreneurial competences to bridge education and work [3]. EntreComp identifies fifteen entrepreneurial competences that can be developed through learning within a progression model that maps across developing autonomy of use and complexity of application, and emphasizes the broadbased potential of these competences to create value for others across the social, cultural, and economic spheres. The framework consists of three interrelated and interconnected competence areas: 'Ideas and opportunities', 'Resources', and 'Into action'. Each of these 
areas comprises five competences, which, together, constitute the building blocks, or threads, of entrepreneurship as competences. The framework describes development of the 15 competences along a progression model, expressed in learning outcomes, over eight levels (see Figure 1.)

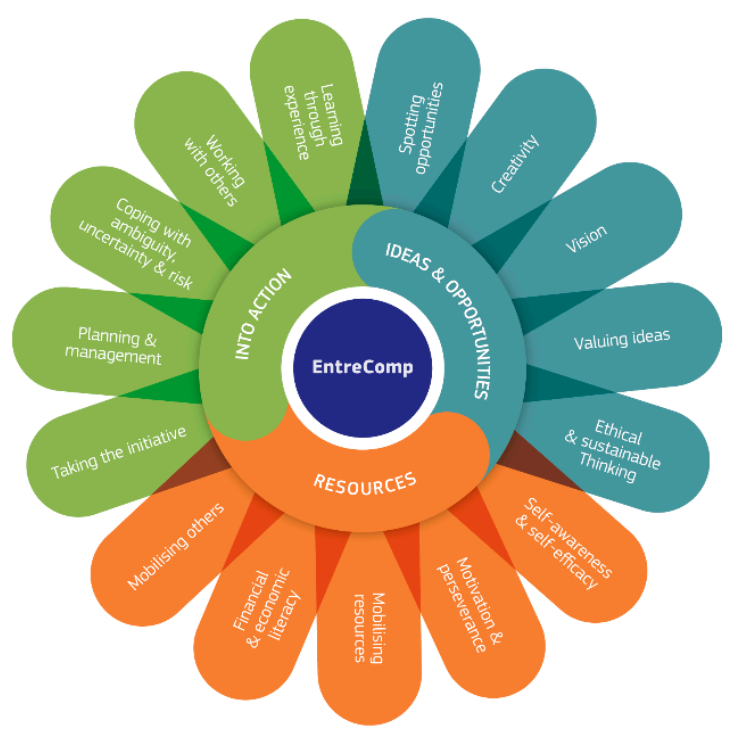

Figure 1. EntreComp Framework [29].

A developing body of studies and research evidences the use of EntreComp across Europe and globally. Stakeholders have translated the original report and framework into thirteen languages to date, with partial translations available in a further three languages. The European Commission has developed a suite of publications driving implementation of the framework into youth-work, education, employment, and enterprise sectors. The most policy-relevant is the 2018 Revision of the European Key Competence Framework, where all European member States agreed to EntreComp as the basis of the entrepreneurship key competence within education and training systems based on the original report published in 2016.

A number of EC documents provide guidance and case examples to promote use of the framework $[29,37]$. The utilization of the EntreComp framework has been broken down into five specific goals: mobilize interest and inspire action; create value by adapting the framework to specific contexts; appraise or assess levels of entrepreneurship competence; implement entrepreneurial ideas and projects; and recognize entrepreneurship skills [29]. The EU has further directed funding towards raising awareness and implementation of EntreComp (e.g., targeted calls via COSME and Horizon2020 with a specific focus on using EntreComp). On a larger scale, the Erasmus+ 2014-2020 program includes development of key competences as a program priority including entrepreneurship and 107 current Erasmus+ projects explicitly mention EntreComp in their application project summary. These initiatives encourage the use of EntreComp to underpin projects related to entrepreneurship key competences. However,, EntreComp as a framework remains less developed and exploited than other European key competence frameworks, such as DigComp, where the first framework version was published in 2013 and development has been supported by well-established European stakeholder networks such as AllDigital. The EntreComp community platform, initiated by the Erasmus+ funded EntreComp360 partnership, will be launched as a community of practice in 2021 to support those using or inspired by the EntreComp framework. The implementation of EE is related to the reflection of both individuals and communities. Next, we will present learning communities in the context of driving changes in education. 


\subsection{Learning Communities of EE Driving Educational Change}

Communities of practice, including communities of learning, have been acknowledged as a powerful method of continuing professional development in education, implementing changes, and sustaining changes [38,39]. Learning is not seen as something that only takes place within the individual, but rather, something that happens through participation in communities of practice [40]. Thus, knowledge is understood as situated in the social context, and its influenced by what is valued in the community. The development of knowledge in a community of learning involves participants collaborating to learn from various resources. [23,39]. We may consider that knowledge management is the process of creating, sharing, using, and managing the knowledge and other information. Therefore, it is also about creating such changes in an organization supporting the most effective knowledge development. [41]. To implement and sustain change, the whole social ecology involved in the development of EE, e.g., stakeholders and influencers of the community of the practice, must participate in the landscapes of learning that educators may belong to $[23,39]$.

Community-based learning refers to a wide variety of instructional methods and programs that can be used to connect classroom teaching to the surrounding community. It is also a pedagogical strategy that intentionally integrates services to the community through classroom learning [42]. The literature describes numerous and diverse benefits of student engagement with community-based learning across multiple domains, including academic development, socio-personal development and civic engagement (e.g., [42-47]. It also supports active citizenship through sustainable development [48], enables and encourages people to take direct actions to tackle the challenges of a rapidly changing, increasingly global world by offering knowledge and skills to improve citizens' lives in sustainable ways (e.g., eco-friendly farming and addressing social and economic inequalities). Greater shared ownership empowers people to shape their community's future and address global issues. This is also acknowledged in international policies, e.g., the UNESCO Institute for Lifelong Learning [49] emphasizes the reciprocal relationship between community-based learning practices and national and local public policies, as both should be guided by a shared vision.

At the same time as we talk about developing learning communities, our discussion has expanded to what we understand by 'real' learning. The analysis of learning has shifted towards the processes of individual educators and learners, as a means of creating an understanding of a learner's reflection, within the broader context of community, institution, policy, and profession. This has laid the foundation for more recent discussion on the broader goals of student learning in a variety of settings, including that of learning professions and communities ([14], see Figure 2.) This learning is most effective when accompanied by metacognitive awareness and analysis of one's own learning processes, supported by membership of a learning community. Indeed, this approach applies to student learning processes, as well as to the learning processes of educators, practitioners, parents, policy makers, and stakeholders [14,21]. Despite recent gains in the profile and reach of entrepreneurship education, the community learning process has been less represented [21]. Therefore, in this study we focus on how the European Union framework for entrepreneurial learning drives key competence development in Europe within learning communities by extending the original framework by Shulman and Shulman ([14], see Figure 2) consisting of four core modules - vision, motivation, practice, and understanding - with integration of the EntreComp framework's goals as described in the following section. 


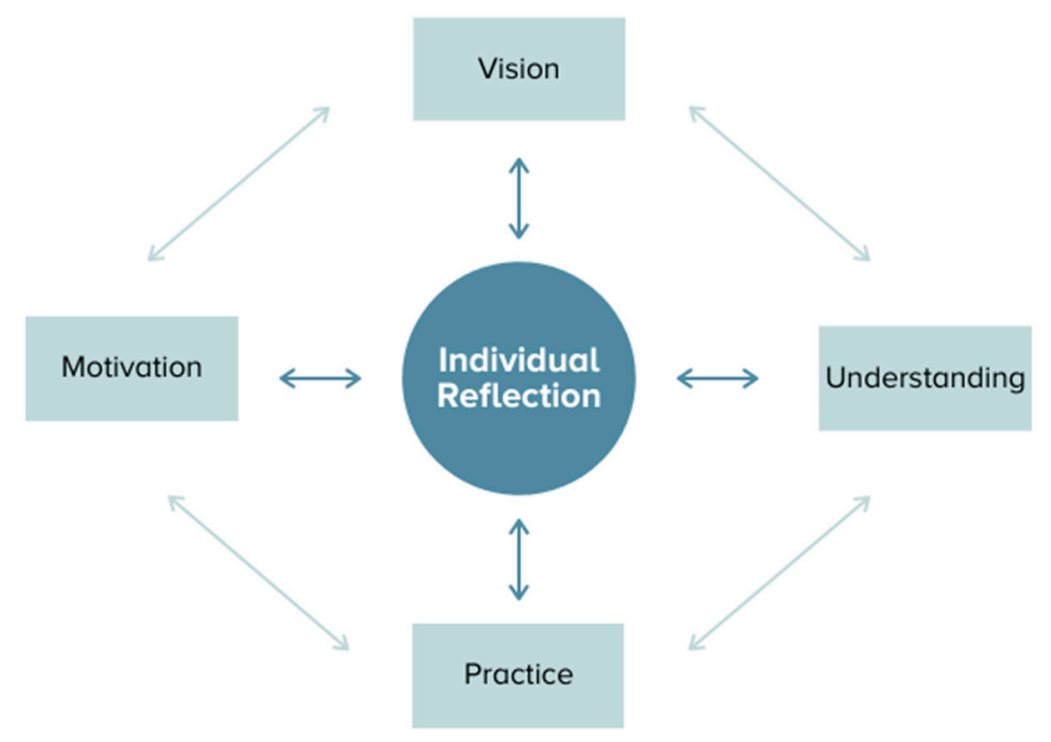

Figure 2. Teacher's learning. Adapted with permission from ref. [14]. Copyright $@ 2021$ Informa UK Limited.

According to the Shulman and Shulman [14] model, an accomplished teacher or other educational practitioner, should be a member of a professional community, and be ready, willing and able to learn from their teaching or other educational experiences. An educator's vision generates the readiness and willingness that induces motivation. Educators should be ready to pursue a vision of a classroom, a school, or other learning unit as a 'learning community' in which teachers and other educators deepen their understanding and are motivated to further develop the forms of pedagogical and organizational practices needed in transforming their visions, motives, and understandings into a functioning, pragmatic reality. When they form learning communities, and work as members of them, the educators are capable of learning from their own and others' experiences through active reflection. Shulman and Shulman [14] also suggest that accomplished educators can smoothly integrate their vision, motivation, understanding, and practice into their teaching or other educational activities through active reflection, which is key to learning and development. Furthermore, Shulman and Shulman highlight the concept of the learning community from a broad perspective, e.g., expanding the learning communities from the classroom to the level of society. Thus, policy-makers and stakeholders can have an essential role in advancing the learning processes of themselves and their communities, expanding the learning communities from micro to macro level in society.

By examining the case of EntreComp employing the Shulman and Shulman [14] approach, we investigate how the framework has been adapted in different national contexts. A comparative approach reveals: what are the learning communities' key reflections and learning processes? What is their vision for the future by implementing EntreComp? What is their motivation for change? How do they perceive and utilize EntreComp?

To conclude, despite all possibilities and efforts in developing education and competencies, the state-of-the-art literature on entrepreneurial behavior promoting sustainable societies still lacks understanding of how entrepreneurial frameworks and strategies strengthen the learning process of communities. With our study, we aim to increase both theoretical and practical understanding of how global strategies, which address entrepreneurial behavior and sustainability, could be operationalized meaningfully in a real-life setting. Therefore, this study contributes to the education development from a practical point of view by investigating how different educational actors, using EntreComp as a European framework for entrepreneurial competences, perceive entrepreneurial learning, how it has been strengthened by the policy framework and how it could be further supported in transnational education contexts. We also expand the theoretical discus- 
sion related to entrepreneurship education from the perspective of education sciences, as there are no unambiguous results or conclusions from previous studies explaining how the educational change related to the development of entrepreneurship education can be efficiently implemented. In this context, we stress the importance of the learning process of communities involving different educational actors. These starting points naturally form our research questions and methodology described in the next section.

\section{Methodology}

\subsection{Data Collection}

An online survey was created in 2020 for policymakers, educators, and other stakeholders. Both quantitative and qualitative data were collected from respondents. The quantitative survey was mainly based on Likert statements in which we used four-point scales. In some cases, respondents had the opportunity to answer, e.g., yes/no. In addition, a few statements were rather practice orientated (e.g., "Do you have an existing example of practice that could be shared with others?"). Often in this respect, the respondents further supplemented their answer with a descriptive, qualitative response. Applying purposive sampling [27], the survey was shared across EntreComp360 project's partner communication channels, through direct mail to existing databases, social media, and broad dissemination across online media to engage actors and networks from youth work, formal education, non-formal education, employment, and enterprise practice and policy organizations. We chose purposive sampling because we wanted to target our survey selectively to the kind of respondents we considered having some previous experience, understanding, or knowledge of entrepreneurship education. Furthermore, we describe that our methodology is based on a case study approach to examine the practical implications of the EntreComp framework. A survey was administered to gather data related to this particular case, being the implementation of the EntreComp, to collect first-hand data from either a small sample or a larger entire population of individuals to describe different aspects and characteristics of the respondents related to the phenomenon. Case studies based on surveys do not involve any experimental manipulation of the conditions, and thus, there was no activity of this type in our study. ([27].)

There were a total of 348 respondents from 47 countries. Since most of the countries had only a few (less than 10) respondents, the comparison between different countries was made using data from only 6 countries (U.K. $(n=52)$, Finland $(n=37)$, Spain $(n=36)$, Germany $(n=35)$, Italy $(n=30)$, and Iceland $(n=27)$. There were 12 NAs). However, in bar plots, we mostly used all the answers when no comparison between different countries was done. The different fields of work the respondents are involved in are described in 4.1. Background Variables. One respondent may be involved in several fields, that is, in many questions one respondent may provide several answers to the same question.

\subsection{The Assessment Frame and Research Questions}

The framework used in this survey, based on the work of Shuman and Shulman [14], Seikkula-Leino [26], and Seikkula-Leino et al. [21,50,51], has been widely used. It has proven effective in qualitatively assessing educators' learning and reflection within education reform. The frame consists of four core modules which are: vision, motivation, practice, and understanding, as described in the literature review. In our study, 'vision' refers to, e.g., these questions: "What kind of outcomes and impact may I proceed with EntreComp?". 'Practice' refers to questions such as: "How could I implement EntreComp in education and training?" while "motivation' refers to: "Would you like to integrate EntreComp into your daily work?". One example of questions referring to 'understanding' is: "Does your work link to some or all of the competences highlighted in EntreComp?"

The survey answers were analyzed by each research question as follows:

1. What is the understanding of EntreComp?

2. What is the motivation for using EntreComp?

3. How is EntreComp implemented in practice? 
4. What is the vision for the future developed by using EntreComp?

Figure 3, derived from previous work by Shuman and Shulman [14] and SeikkulaLeino [26], and complemented with EntreComp goals, illustrates how individual reflections within learning communities play a crucial part in educational reform related to entrepreneurship education.

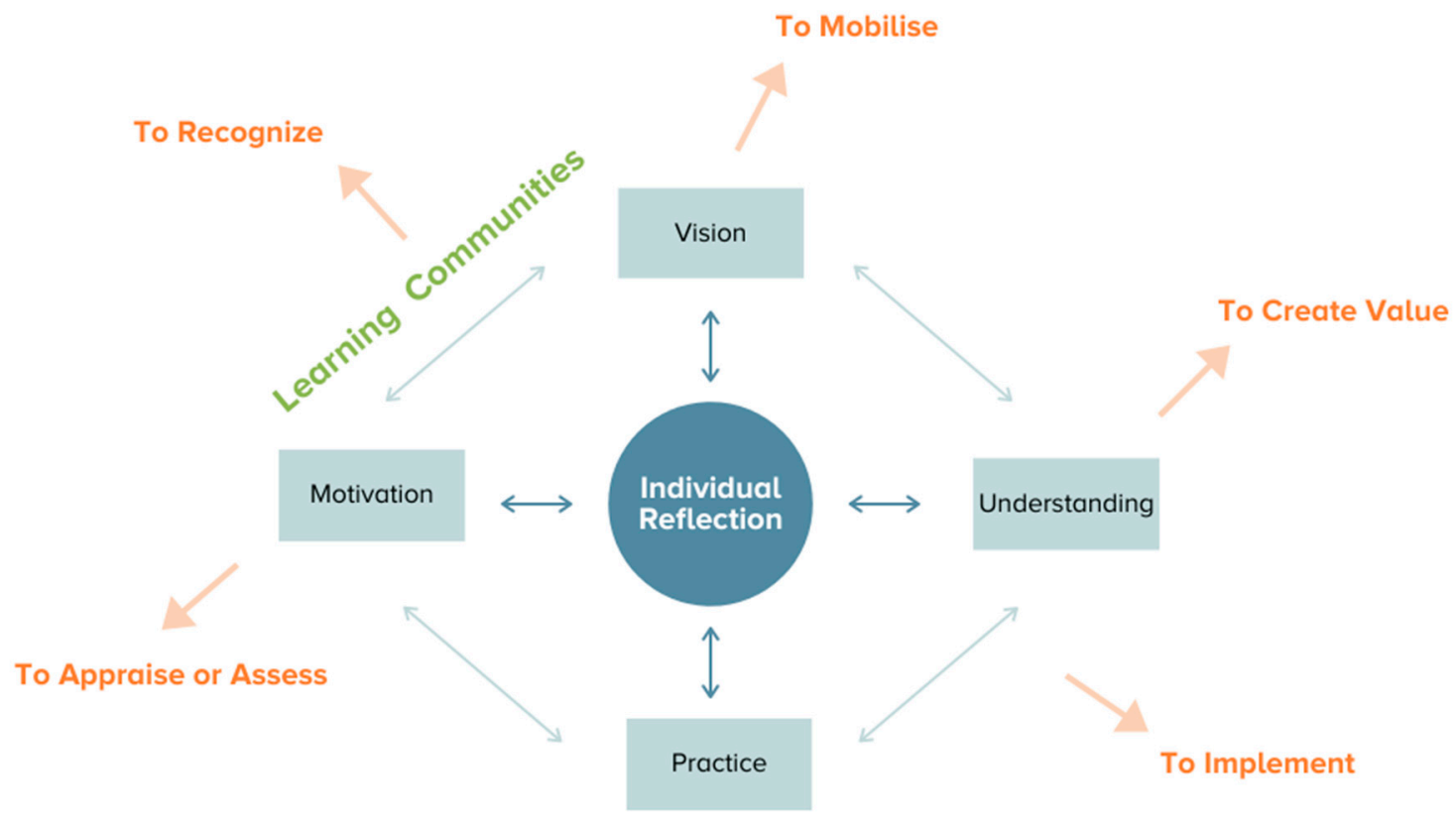

Figure 3. The framework for data collection and analysis.

To transform EE, the implementation of EntreComp in European policymaking relies upon the five goals of EntreComp: mobilize, create value, implement, appraise or assess, and recognize. However, to initiate these goals, individuals and communities also need motivation, vision, understanding of the need for reform, and how to implement these goals in practice, which are the starting points for our survey design, implementation, and data analysis.

\subsection{Data Analysis Methods}

The quantitative data showing a comparison of countries were analyzed by analysis of variance (Kruskall-Wallis rank sum test). The qualitative data gathered through openended survey questions were analyzed using content analysis following the logic of the theoretical propositions guiding the overall design of the survey based on Figure 3, which also created the basis for organizing the data to draw conclusions [52]. The data were grouped into parallel types by searching for similarities in the data. It is based on theme categorization and grouping, and is a valuable method for illustrating research problems with practical examples (e.g., [27]). By using content analysis, we aimed to find answers to the set research questions by concentrating on respondents' views on entrepreneurship education and the EntreComp framework. The content analysis was realized as follows:

1. The data collected from different countries and with different languages were translated into English.

2. Then, the survey data were read several times to try to construct an overall picture of the responses, including the elements of how entrepreneurship education was described.

3. The data were read more reflectively and analytically, organizing the data through the questions answered by the respondents. 
4. The answers were mirrored against our literature review and concept definitions, involving, for example, different aspects of reflection in learning communities (e.g., vision, motivation, practice, and understanding). Similar types of answers were grouped.

5. The above data analysis was integrated, allowing analysis of the respondents' reflections in the context of entrepreneurship education and EntreComp.

\section{Results}

\subsection{Background Variables}

A country comparison was realized between the U.K., Finland, Spain, Germany, Italy, and Iceland. First, we present the respondents' job descriptions. One respondent may be involved in several fields, so the comparison of different job fields is not possible.

In Figure 4 it can be seen that the education sector is strongly represented among the respondents. Many of them $(\mathrm{n}=155)$ work in the field of higher education, adult education or adult inclusion $(n=114)$, vocational education and training $(n=112)$, nonformal youth education ( $n=105)$, and start-up or business growth support $(n=104)$. Only 15 respondents worked in the field of human resources. There were 35 respondents who work in unspecified fields. Next, we explain respondents' understandings of EntreComp while highlighting country-specific differences-what they know about EntreComp in general, and how it relates to their work.

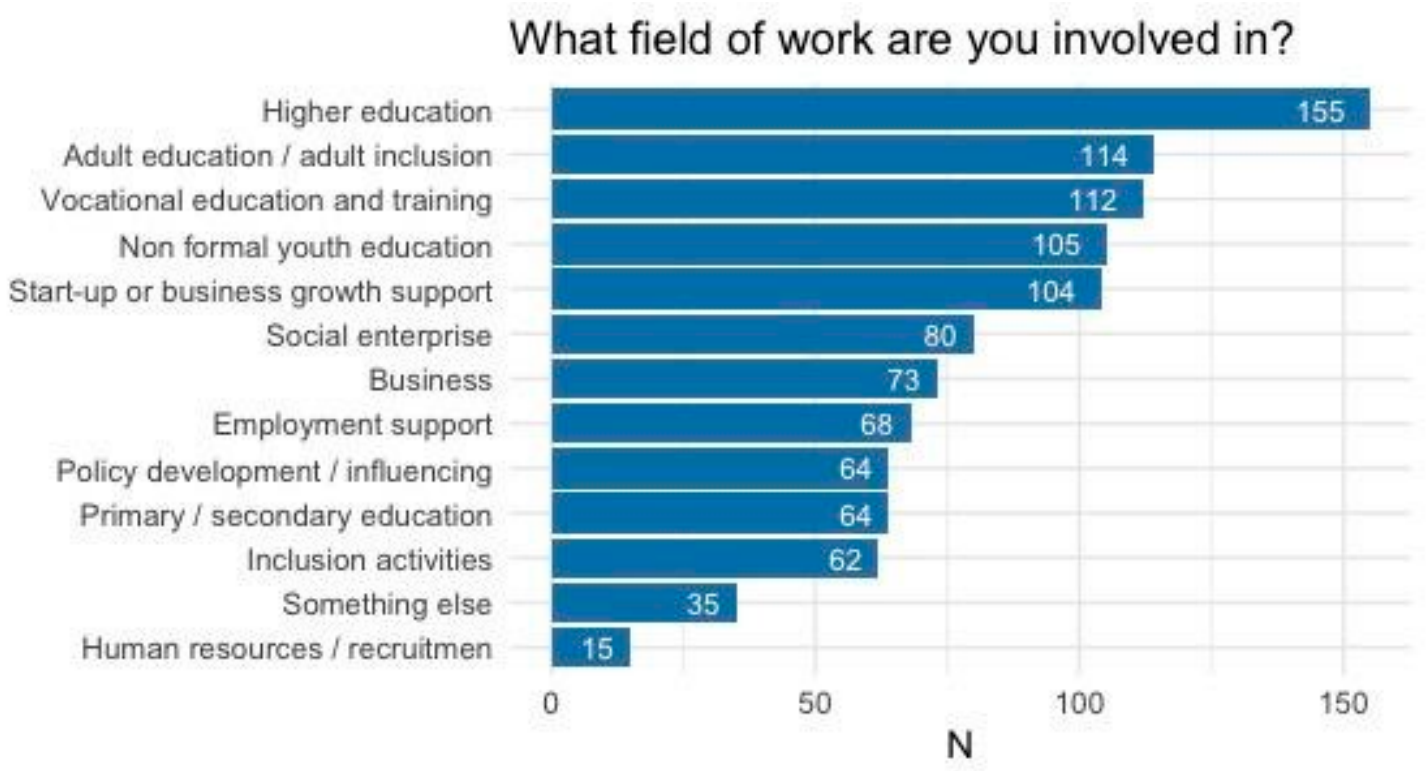

Figure 4. The respondents' professional backgrounds.

\subsection{What Is the Understanding of EntreComp?}

Almost half of all the respondents, $49.1 \%(n=171)$, were familiar with the EntreComp framework, $21.3 \%(n=74)$ had heard something about it, and $29.3 \%(n=102)$ of the respondents had not heard about EntreComp at all. One respondent did not answer. In the comparison of the six countries related to the question, 'Are you familiar with EntreComp?', the differences between countries were statistically significant $\left(p\right.$-value $\left.=2.187 \times 10^{-11}\right)$. The significance of the comparisons was obtained using the Kruskal-Wallis rank sum test. Table 1 shows that in the U.K, (67.3\%), Spain (63.9\%), and Italy $(76.7 \%)$, most of the respondents were familiar with EntreComp. On the other hand, in Germany (65.7\%) and Iceland $(70.4 \%)$, most of the respondents had not heard about EntreComp. 
Table 1. Are you familiar with EntreComp?

\begin{tabular}{|c|c|c|c|c|c|c|}
\hline & Finland & Germany & Iceland & Italy & Spain & U.K. \\
\hline Yes & $\begin{array}{c}16 \\
(43.2 \%)\end{array}$ & $\begin{array}{c}8 \\
(22.9 \%)\end{array}$ & $\begin{array}{c}2 \\
(7.4 \%)\end{array}$ & $\begin{array}{c}23 \\
(76.7 \%)\end{array}$ & $\begin{array}{c}23 \\
(63.9 \%)\end{array}$ & $\begin{array}{c}35 \\
(67.3 \%)\end{array}$ \\
\hline Heard something about it & $\begin{array}{c}11 \\
(29.7 \%)\end{array}$ & $\begin{array}{c}4 \\
(11.4 \%)\end{array}$ & $\begin{array}{c}6 \\
(22.2 \%)\end{array}$ & $\begin{array}{c}3 \\
(10.0 \%)\end{array}$ & $\begin{array}{c}6 \\
(16.7 \%)\end{array}$ & $\begin{array}{c}11 \\
(21.2 \%)\end{array}$ \\
\hline No & $\begin{array}{c}10 \\
(27.0 \%)\end{array}$ & $\begin{array}{c}23 \\
(65.7 \%)\end{array}$ & $\begin{array}{c}19 \\
(70.4 \%)\end{array}$ & $\begin{array}{c}4 \\
(13.3 \%)\end{array}$ & $\begin{array}{c}7 \\
(19.4 \%)\end{array}$ & $\begin{array}{c}6 \\
(11.5 \%)\end{array}$ \\
\hline & & & & & \multicolumn{2}{|c|}{ Sig. $=2.187 \times 10^{-11}$} \\
\hline
\end{tabular}

In the quantitative question 'EntreComp is about promoting entrepreneurial learning. How much does the concept of entrepreneurial learning link to your work?': 12.6\% $(n=44)$ of all the respondents argued that 'This is the main theme of my work'; $32.8 \%(\mathrm{n}=114)$ 'Plays a big part in my work'; $35.1 \%(\mathrm{n}=122)$ 'Relevant and included in my work to some extent'; $12.4 \%(\mathrm{n}=43)$ 'Relevant but not (yet) included in my work'; and 2.3\% $(\mathrm{n}=8)$ 'Not relevant to my work'. 17 did not answer.

When comparing the six countries, the comparison is statistically significant with $p$-value $=4.32 \times 10^{-6}$ (Table 2). In Finland, Germany, and Spain, most of the respondents answered that the quantitative question, 'How much does the concept of entrepreneurial learning link to your work?', is relevant and included in their work to some extent. In the U.K. and Italy most of the respondents answered that it plays a big part in their work. In Iceland most of the respondents answered that it is relevant and included in their work to some extent. It can be concluded that entrepreneurial learning does link to many respondents' work. In the U.K. almost one third thought that it is the main theme of their work.

Table 2. How much does the concept of entrepreneurial learning link to your work?

\begin{tabular}{|c|c|c|c|c|c|c|}
\hline & Finland & Germany & Iceland & Italy & Spain & U.K. \\
\hline \multirow{2}{*}{ This is the main theme of my work } & 2 & 1 & 2 & 3 & 6 & 14 \\
\hline & $5.7 \%$ & $3.0 \%$ & $7.7 \%$ & $10.0 \%$ & $17.1 \%$ & $29.2 \%$ \\
\hline \multirow{2}{*}{ Plays a big part in my work } & 6 & 11 & 6 & 14 & 11 & 22 \\
\hline & $17.1 \%$ & $33.3 \%$ & $23.1 \%$ & $46.7 \%$ & $31.4 \%$ & $45.8 \%$ \\
\hline \multirow{2}{*}{ Relevant and included in my work to some extent } & 19 & 13 & 9 & 9 & 13 & 10 \\
\hline & $54.3 \%$ & $39.4 \%$ & $34.6 \%$ & $30.0 \%$ & $37.1 \%$ & $20.8 \%$ \\
\hline \multirow{2}{*}{ Relevant but not (yet) included in my work } & 6 & 6 & 7 & 4 & 5 & 2 \\
\hline & $17.1 \%$ & $18.2 \%$ & $26.9 \%$ & $13.3 \%$ & $14.3 \%$ & $4.2 \%$ \\
\hline \multirow{3}{*}{ Not relevant to my work } & 2 & 2 & 2 & 0 & 0 & 0 \\
\hline & $5.7 \%$ & $6.1 \%$ & $7.7 \%$ & $0.0 \%$ & $0.0 \%$ & $0.0 \%$ \\
\hline & & & & & \multicolumn{2}{|c|}{ Sig. $=4.32 \times 10^{-6}$} \\
\hline
\end{tabular}

A majority of respondents, $61.5 \%(\mathrm{n}=214)$, answered 'Yes' to the quantitative question 'Does your work link to some or all of the competences highlighted in EntreComp', 29.9\% $(\mathrm{n}=104)$; 'Partially-in some ways', $2.3 \%(\mathrm{n}=8)$; 'Not yet, but interested', $0.1 \%(\mathrm{n}=3)$; ' $\mathrm{No}^{\prime}$ and $5.5 \%$ did not answer $(\mathrm{n}=19)$.

The results of the comparison between countries were parallel to the previous ones. Most of the respondents in Germany and Iceland answered that their work links partially to some or all of the competences highlighted in EntreComp (Table 3). In Finland, Italy, Spain, and the U.K. the most common answer was that their work links to some or all of the competences highlighted in EntreComp. Altogether, it can be seen that almost all of the respondents' work links to the competences highlighted in EntreComp in some ways. 
Table 3. Does your work link to some or all of the competences highlighted in EntreComp?

\begin{tabular}{|c|c|c|c|c|c|c|}
\hline & Finland & Germany & Iceland & Italy & Spain & U.K. \\
\hline Yes & $\begin{array}{c}23 \\
(67.6 \%)\end{array}$ & $\begin{array}{c}15 \\
(46.9 \%)\end{array}$ & $\begin{array}{c}12 \\
(46.2 \%)\end{array}$ & $\begin{array}{c}18 \\
(60.0 \%)\end{array}$ & $\begin{array}{c}22 \\
(62.9 \%)\end{array}$ & $\begin{array}{c}42 \\
(87.5 \%)\end{array}$ \\
\hline Partially_in some ways & $\begin{array}{c}9 \\
(26.5 \%)\end{array}$ & $\begin{array}{c}17 \\
(53.1 \%)\end{array}$ & $\begin{array}{c}13 \\
(50.0 \%)\end{array}$ & $\begin{array}{c}10 \\
(33.3 \%)\end{array}$ & $\begin{array}{c}11 \\
(31.4 \%)\end{array}$ & $\begin{array}{c}6 \\
(12.5 \%)\end{array}$ \\
\hline Not yet, but interested & $\begin{array}{c}0 \\
(0.0 \%) \\
\end{array}$ & $\begin{array}{c}0 \\
(0.0 \%) \\
\end{array}$ & $\begin{array}{c}1 \\
(3.8 \%) \\
\end{array}$ & $\begin{array}{c}2 \\
(6.7 \%)\end{array}$ & $\begin{array}{c}2 \\
(5.7 \%) \\
\end{array}$ & $\begin{array}{c}0 \\
(0.0 \%)\end{array}$ \\
\hline No & $\begin{array}{c}2 \\
(5.9 \%)\end{array}$ & $\begin{array}{c}0 \\
(0.0 \%)\end{array}$ & $\begin{array}{c}0 \\
(0.0 \%)\end{array}$ & $\begin{array}{c}0 \\
(0.0 \%)\end{array}$ & $\begin{array}{c}0 \\
(0.0 \%)\end{array}$ & $\begin{array}{c}0 \\
(0.0 \%)\end{array}$ \\
\hline
\end{tabular}

In the last question (quantitative), 'If entrepreneurial learning is not in the focus of your activities, are there other learning activities related to helping people such as those which allow young people or adults to transform ideas and opportunities, by mobilizing resources, into action?' $48.3 \%(n=168)$ of all the respondents answered 'Yes'; $26.4 \%(n=92)$ 'Partially-in some ways'; 8.0\% $(\mathrm{n}=28)$ 'Not yet, but interested'; 5.7\% $(\mathrm{n}=20)$ 'No'; and $11.5 \%(\mathrm{n}=40)$ did not answer. The differences in comparison of the six countries was not statistically significant $(p=0.0842)$ (Table 4 .).

Table 4. If entrepreneurial learning is not in the focus of your activities, are there other learning activities related to helping people such as those which allow young people or adults to transform ideas and opportunities, by mobilizing resources, into action?

\begin{tabular}{|c|c|c|c|c|c|c|}
\hline & Finland & Germany & Iceland & Italy & Spain & U.K. \\
\hline Yes & $\begin{array}{c}23 \\
(67.6 \%)\end{array}$ & $\begin{array}{c}18 \\
(58.1 \%)\end{array}$ & $\begin{array}{c}9 \\
(39.1 \%)\end{array}$ & $16(59.3 \%)$ & $11(35.5 \%)$ & $\begin{array}{c}23 \\
(54.8 \%)\end{array}$ \\
\hline Partially-in some ways & $\begin{array}{c}9 \\
(26.5 \%)\end{array}$ & $\begin{array}{c}10 \\
(32.3 \%)\end{array}$ & $\begin{array}{c}11 \\
(47.8 \%)\end{array}$ & $\begin{array}{c}9 \\
(33.3 \%)\end{array}$ & $13(41.9 \%)$ & $\begin{array}{c}11 \\
(26.2 \%)\end{array}$ \\
\hline Not yet, but interested & $\begin{array}{c}1 \\
(2.9 \%)\end{array}$ & $\begin{array}{c}1 \\
(3.2 \%)\end{array}$ & $\begin{array}{c}3 \\
(13.0 \%)\end{array}$ & $\begin{array}{c}1 \\
(3.7 \%)\end{array}$ & $\begin{array}{c}4 \\
(12.9 \%)\end{array}$ & $\begin{array}{c}4 \\
(9.5 \%)\end{array}$ \\
\hline No & $\begin{array}{c}1 \\
(2.9 \%)\end{array}$ & $\begin{array}{c}2 \\
(6.4 \%)\end{array}$ & $\begin{array}{c}0 \\
(0.0 \%)\end{array}$ & $\begin{array}{c}1 \\
(3.7 \%)\end{array}$ & $\begin{array}{c}3 \\
(9.7 \%)\end{array}$ & $\begin{array}{c}4 \\
(9.5 \%)\end{array}$ \\
\hline
\end{tabular}

Next, we will present the results of the research based on the theorical frame (vision, motivation, practice, and understanding).

\subsection{What Is the Motivation for Using EntreComp?}

In the quantitative question, 'Do you already use EntreComp as a model or as inspiration for your work on developing entrepreneurial competences?',' one could answer 'Yes', 'No, but I would like to include it in my work', or 'No'. Some respondents omitted this question. The frequencies are described as a bar plot in Figure 5. From the figure we see, for example, that slightly less than half (ca. 42\%) of the respondents are developing entrepreneurial competences by using the EntreComp framework.

The comparison of the six countries shows (Table 5) that most respondents in Iceland (57.7\%) did not use EntreComp as a model/inspiration for their work on developing entrepreneurial competences, but they would like to. In Finland, Italy, Spain, and the U.K. the vast majority of respondents already use EntreComp as a model/inspiration for their work on developing entrepreneurial competences. In Germany, most respondents (42.4\%) answered no. The comparison is statistically significant $\left(p=2.016 \times 10^{-7}\right)$. 
Table 5. Do you already use EntreComp as a model or as inspiration for your work on developing entrepreneurial competencies?

\begin{tabular}{|c|c|c|c|c|c|c|}
\hline & Finland & Germany & Iceland & Italy & Spain & U.K. \\
\hline Yes & $\begin{array}{c}15 \\
(42.9 \%)\end{array}$ & $\begin{array}{c}6 \\
(18.2 \%)\end{array}$ & $\begin{array}{c}1 \\
(3.8 \%)\end{array}$ & $\begin{array}{c}18 \\
(60.0 \%)\end{array}$ & $\begin{array}{c}16 \\
(45.7 \%)\end{array}$ & $\begin{array}{c}29 \\
(60.4 \%)\end{array}$ \\
\hline $\begin{array}{l}\text { No-but I would like to } \\
\text { include it in my work }\end{array}$ & $\begin{array}{c}12 \\
(34.3 \%)\end{array}$ & $\begin{array}{c}13 \\
(39.4 \%)\end{array}$ & $\begin{array}{c}15 \\
(57.7 \%)\end{array}$ & $\begin{array}{c}11 \\
(36.7 \%)\end{array}$ & $\begin{array}{c}13 \\
(37.1 \%)\end{array}$ & $\begin{array}{c}14 \\
(29.2 \%)\end{array}$ \\
\hline \multirow[t]{2}{*}{ No } & $\begin{array}{c}8 \\
(22.9 \%)\end{array}$ & $\begin{array}{c}14 \\
(42.4 \%)\end{array}$ & $\begin{array}{c}10 \\
(38.5 \%)\end{array}$ & $\begin{array}{c}1 \\
(3.3 \%)\end{array}$ & $\begin{array}{c}6 \\
(17.1 \%)\end{array}$ & $\begin{array}{c}5 \\
(10.4 \%)\end{array}$ \\
\hline & & & & & \multicolumn{2}{|c|}{ Sig. $=2.016 \times 10^{-7}$} \\
\hline
\end{tabular}

In the quantitative question, 'What would encourage you to become part of our EntreComp community?', one respondent may provide several answers. The choices were 'Sharing case studies or practices linked to my work' $(n=180)$; 'Contribute to research on ways to develop this work further at national/EU level—inform the next steps development of EntreComp' ( $\mathrm{n}=165)$; 'Putting me and/or my organization on the global map of EntreComp users' ( $\mathrm{n}=163$ ); 'Access to professional development via online training or MOOCs' $(\mathrm{n}=136)$; 'Becoming recognized as an EntreComp ambassador' $(\mathrm{n}=115)$; 'Profiling and sharing my work through articles, blog posts or webinars' ( $\mathrm{n}=113)$; and 'Other (please specify)' $(\mathrm{n}=26)$. The frequencies of each answer are in parentheses after the answer alternative.

Answers to the question 'What are the best ways to connect you to an online EntreComp community?' are plotted as bars in Figure 6. The question includes quantitative responses and a qualitative response in the option 'Other'. Thus, we may conclude that LinkedIn and Facebook are the best platforms to build online connections with future community partners.

\section{Do you already use EntreComp as a model or as an inspiration for your work developing entrepreunial competencies?}

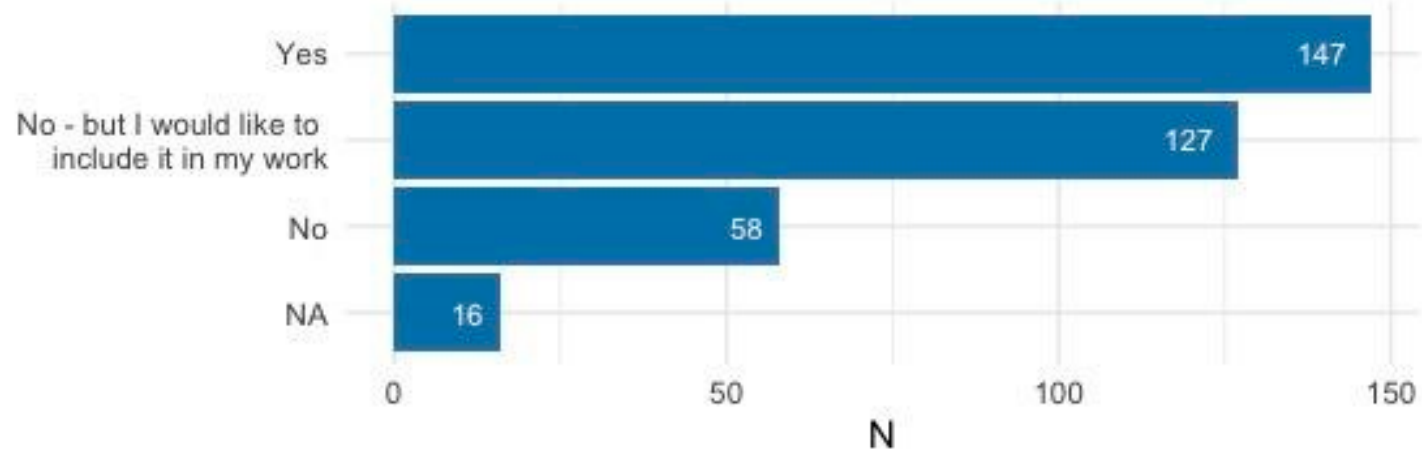

Figure 5. The utilization of EntreComp.

\subsection{How Is EntreComp Implemented in Practice?}

Because our study specifically sought to identify the factors that may make it challenging to implement EntreComp in order to create, e.g., future practices of EntreComp, we focused our questions primarily on these challenges rather than opportunities or other aspects. Therefore, our results are highlighted with an emphasis on the critical entry angle. 


\section{What are the best ways to connect you to an online EntreComp community?}

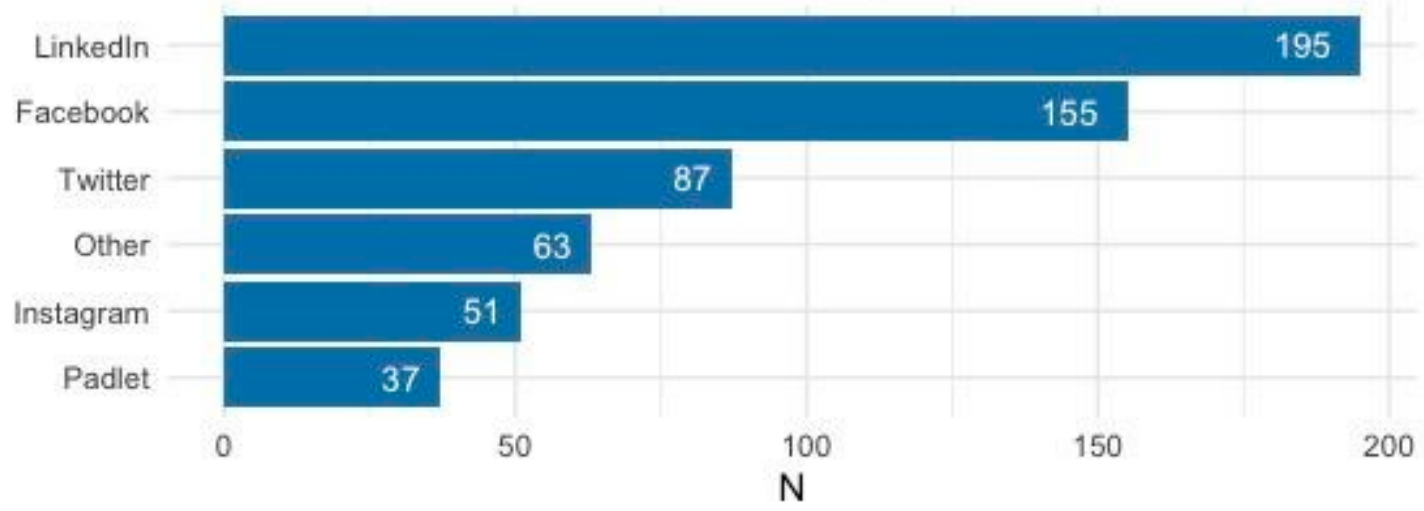

Figure 6. Social media in the community development of EntreComp.

Implementation of the EntreComp framework was reported to include some challenges. Respondents find it time-consuming, difficult to understand, and the lack of language selection is problematic. Respondents already using EntreComp use it in all five areas (to mobilize, to create value, to implement, to assess, and to recognize), but mostly 'TO MOBILIZE - raise awareness and understanding of these competences' $(n=63)$ and 'TO MOBILIZE-inspire or engage new people or organizations into entrepreneurial learning' $(n=60)$. Again, it was possible to have several answers to the same (quantitative) question.

In an open-ended response question, 40 respondents had found, or were aware of, barriers that might prevent them or others from using EntreComp. For six respondents, language hindered use of the EntreComp framework. Two of the six respondents found the language options too limited, whereas, one respondent thought that the nuances in meaning of different languages makes translation challenging. Two respondents found time consumption to be a barrier and two respondents found the framework difficult to understand. Furthermore, four respondents faced unspecified barriers and three respondents found the framework to be difficult to use: e.g., one respondent described the appendix consisting of the list of skills to be difficult to use.

In another open-ended response question, 40 respondents expressed concerns about using EntreComp, with four respondents finding it too vast, and two respondents finding that they did not fully understand it. It was suggested to try to simplify it and to have a 'use directly tool', as the framework was seen to be rather theoretical. In addition, measuring the impact of entrepreneurial learning was considered to be difficult. There were also concerns about translating the framework into non-Western cultural contexts.

\subsection{How the Vision for the Future Is Developed by Using EntreComp?}

Of the 70 responses to the open-ended question, 'What is your vision for using EntreComp?', 10 respondents reported their visions relating to young people recognizing their own entrepreneurial skills, with 22 respondents highlighting application of the framework to different areas of life. Seven respondents' visions emphasized the possibility of sharing good practices, consulting, and networking.

In the quantitative question, 'How can we help you?', presenting practical examples of how to support respondents to include EntreComp in their area of work, respondents may select more than one response. The choices were: 'Resources that explain the value of entrepreneurial competences', $(\mathrm{n}=150)$; 'Help to mobilize others on the relevance of EntreComp in my area of work', $(\mathrm{n}=75)$; 'Practical examples of how to include EntreComp in my area of work', $(\mathrm{n}=203)$; 'Online training on EntreComp in my area of work', $(\mathrm{n}=141)$; 'Demonstrating the value of entrepreneurial learning', $(n=136)$; 'Being part of a community of people interested in developing and using EntreComp or entrepreneurial competences', $(\mathrm{n}=169)$; 'High profile recognition for using EntreComp at individual or organizational 
level', ( $\mathrm{n}=97)$; 'Partner searching/matching to develop new tools or projects based on EntreComp/entrepreneurial competences', $(\mathrm{n}=155)$; 'Understanding how to evaluate learning or working performance related to EntreComp competences', $(\mathrm{n}=152)$; 'Having guidance on how to assess progress in the EntreComp competences', ( $\mathrm{n}=142)$; and 'Other', $(n=20)$.

There were a total of 112 responses to the open-ended question: 'This online community is about making EntreComp more easy-to-understand and easy to use. Do you have any suggestions?'. 15 respondents suggested using practical cases and examples to realistically implement the concept behind the model. Five respondents recommended that the model should be available in languages other than English, also reflecting non-European cultures. Four people said that instructional videos would be valuable. Twelve respondents suggested an online forum or Skype/Teams meetings to promote better understanding and use of EntreComp. Two respondents suggested face-to-face meetings and two suggested that the terminology should be tailored to target specific groups.

In an open-ended question concerning good practices, 49 respondents had found or were aware of successes or good practices that would encourage others to use EntreComp: 15 responded 'No'; 284 did not respond at all; and 14 respondents answered 'Yes' without giving examples. Nine respondents reported using EntreComp to teach different skills in different practices. For example, they had had project-based approaches, workshops, and 'normal' classes online. The target groups mentioned ranged from young children to young apprentices, university students, and the elderly.

\section{Discussion}

The aims of the recent EU policy documents (e.g., [2]) to foster entrepreneurial skills can be clearly seen within many EU-funded project initiatives, such as the development of the EntreComp framework. Even though fostering entrepreneurial skills is recognized to be globally important (e.g., UN SDGs), the effective implementation, and translation into practice, of the education policy documents remains complex. Therefore, this paper focused on analyzing how a cross section of actors, using EntreComp as a European framework for entrepreneurial competences, see that entrepreneurial learning has been realized and could be further supported in transnational education contexts. The results from the online survey generated new knowledge on how the EntreComp framework can guide the collaborative creation of a future vision for education; how well it is recognized, implemented, and understood in practice; and how it motivates and supports realization of educational change, which emphasizes the value of entrepreneurial competencies. The aim was to reveal how EU policies can drive educational change in Europe illustrated by the case of EntreComp.

Our results reveal that overall awareness and understanding of entrepreneurial education are 'improving' compared with earlier works, in which similar kinds of research settings and data collection were used $[15,26,50]$. According to those previous studies, there is a need for the development of all aspects in reflection: vision, motivation, practice, and understanding. However, these were not the results in our case study. It can be stated that the EntreComp framework driving entrepreneurial learning is relevant to most of the respondents' work. Moreover, the majority of respondents are motivated to integrate EntreComp in their work. Therefore, we may conclude that EntreComp can work in practice to strengthen the entrepreneurial capacity of European citizens and organizations (e.g., [3]). This is also supported by Dinning's [6] and Gerbutt et al.'s [7]) previous studies on EntreComp and entrepreneurial competencies. However, there might be some sampling error, thus raising the concern of bias in the chosen data collection method. As an example, in some situations, responses came by EntreComp projects. In some cases, answers were collected randomly from the education sector, without any connection to EntreComp. Furthermore, the number of responses is still low to conclude, e.g., the European situation of implementing EntreComp in practice. 
However, our study also stressed that the implementation of entrepreneurial education initiatives driven by international policy goals is challenging. For example, the respondents estimated that adapting the EntreComp framework is time-consuming and it is difficult to understand the framework conceptually. On a more practical level, the lack of widely available translations of EntreComp is problematic. Furthermore, the need for training and guidance is highlighted to promote effective implementation. The respondents that already use EntreComp in their work, use it in all five areas (to mobilize, to create value, to implement, to assess, and to recognize) but mostly 'TO MOBILIZE-raise awareness and understanding of these competences', and 'TO MOBILIZE-inspire or engage new people or organizations into entrepreneurial learning'. These results imply that currently the implementation of EntreComp is mostly related to awareness-raising on entrepreneurial education and inspiring students, curricula developers and educators, and may indicate that EntreComp is at an early stage in the implementation journey.

These same aspects were highlighted in the answers in which respondents explain their future visions related to using the EntreComp framework. However, the descriptions of the respondents' visions are relatively modest, e.g., none of them described any future changes (societal, economic, or environmental) that they would like to see resulting from entrepreneurial education. This challenge related to the lack of understanding of EE in general and is also recognized in many previous studies (e.g., $[15,26])$. This finding is supported by the results of the survey, which indicate that almost one third of the respondents would require more support to be able to better demonstrate the value added by EE. Therefore, the potential impact and benefits of entrepreneurship education still require more explicit articulation and promotion $[21,26,50,51]$, as well as more solid theoretical underpinning [13]. This need was also reflected by respondents who highlighted the importance of evaluating the outcomes and impacts of entrepreneurship education.

According to the results, they key factors motivating respondents to use the EntreComp framework include the following: being psychologically and socially part of the EntreComp learning community in which recognition and support of individual and community entrepreneurial initiatives and activities are highlighted as valuable to promotion of EntreComp. It is thus important to note that the learning processes of the developers of entrepreneurship education play an important role in making progress in educational reforms in practice (e.g., [12,16]). This downplays the role and effectiveness of the traditional education policymakers, such as the state, as primary drivers of educational progress (e.g., [31]). Indeed, effective learning requires participation, e.g., feedback and encouragement (e.g., [53]), which is also relevant for the future development of such competence frameworks. Thus, further studies are still needed on how both individual and community learning processes can be integrated into the designing of policy tools, e.g., frames and roadmaps, to support a more effective implementation of the EE-related reforms. However, we may say that our study contributes the theoretical discussion in the field of entrepreneurship education by integrating 'the reflection process of learners', borrowing mainly the significant outcomes and frameworks from curriculum and curriculum reform studies (e.g., $[14,15,26])$ to widen and deepen the understanding of factors influencing on the successful education change.

The respondents also suggested that ideas and best practices, related to implementation of the EntreComp framework, should be shared with other developers, e.g., through case study presentations. This draws attention to effective communication mechanisms within and between different learning communities. As an example, by highlighting individual success stories, significant psychological support and encouragement can be provided, which, according to the survey results, is one of the key areas for future development of the EntreComp framework. This learning proceeds most effectively if it is accompanied by metacognitive awareness and analysis of one's learning processes and is supported by membership in a learning community (e.g., [17-20,54]).

Adapting the community learning approach might be beneficial for further enhancing students' learning processes as well as to the learning processes of, e.g., educators, other 
practitioners, parents, policymakers, and stakeholders [14,23]. Respondents highlight the importance of 'belonging and recognition' throughout the survey. This implies that a reciprocal relationship between community-based learning practices and national and local public policies is needed for seamless enforcement of educational aims [49]. From this perspective, the development of the learning communities in a transnational context should also be given more attention. The learning community can often only be perceived too narrowly, only relating to the physically close, e.g., regional, community. However, the learning communities have become global and they are not solely tied to certain locations and can be digital, particularly in the COVID era when interaction is increasingly online. As a result, these learning communities can be global in reach and involve actors working at all levels, e.g., educators, stakeholders, policymakers, students, and private sector partners. Therefore, further studies are needed on how to promote the psychosocial learning processes of international communities, e.g., through adapting new technologies?

This becomes apparent, especially when looking at country differences as revealed by the results. This raises questions of whether global entrepreneurial learning communities could be developed more effectively, despite the country divergence, across lifelong learning policy and practice? Based on the survey results, we were able to identify three progress scenarios related to the implementation of the EntreComp framework: (a) in the U.K. and Italy, most of the respondents answered that EntreComp already plays a big part in their work; (b) in Finland, Germany, and Spain, most of the respondents feel that EntreComp is relevant and included in their work to some extent; and (c) in Iceland the respondents think their work links partially to some or all of the competences highlighted in EntreComp. However, EntreComp is not greatly utilized in their practical work. Thinking about these three scenarios, it would be valuable to examine how different cultural paths and educational policy factors guide the implementation of similar frameworks on a national level. In this study, we were able to indicate country-specific differences, but not the reasons behind them. Indeed, studying educational reform is not a straightforward process: it involves developing understanding of different cultures, policies, rationality, and emotional dimensions, which play a high role when adopting new approaches to education (e.g., [25]). Our findings might provide a new starting point for further investigation of future design and implementation of education policies; as a next step, we propose collecting a broader data set from a more comprehensive, global sample of respondents, which would further develop the understanding of how entrepreneurial education initiatives can be efficiently and effectively implemented in different regions, countries, and cultures.

Since, e.g., The United Nations' Sustainable Development Goals and The European Union promote entrepreneurial competencies as a means of supporting young people to innovate, start businesses and create jobs, and creating welfare and economic sustainability, we focused our study on this area. Therefore, we conclude that our findings support that our educational initiatives are on 'the right track'. However, more research and practical implications are needed to promote a 'real' change in education. In this context, we highlight, e.g., communities' reflection and learning processes, thus supporting the development of a concrete vision for a 'better sustainable world' and pedagogical and practical ideas to take into use.

\section{Conclusions}

This paper extensively focused on the development of entrepreneurship education at the European level by examining how the EntreComp framework can act as an engine for transnational policy implementation driving entrepreneurial competences. This is the first time an entrepreneurship education study has respondents from so many different countries (46). Such major international studies have previously been, e.g., global reviews of studies conducted on entrepreneurship education in teacher education (e.g., [55]). Furthermore, previous country comparisons were limited to fewer countries (e.g., [15]). In that regard, our findings provide new insights into the overall progress of entrepreneurship education in the European context. However, its key contribution is linked to previ- 
ous entrepreneurship education research by integrating the Shulman and Shulman [14], Seikkula-Leino [26], and Seikkula-Leino et al. [21,50,51], theoretical framework to other relevant studies [26] and the conceptual EntreComp framework's goals: mobilize, create value, implement, appraise or assess, and recognize [3] as summarized in Figure 7.

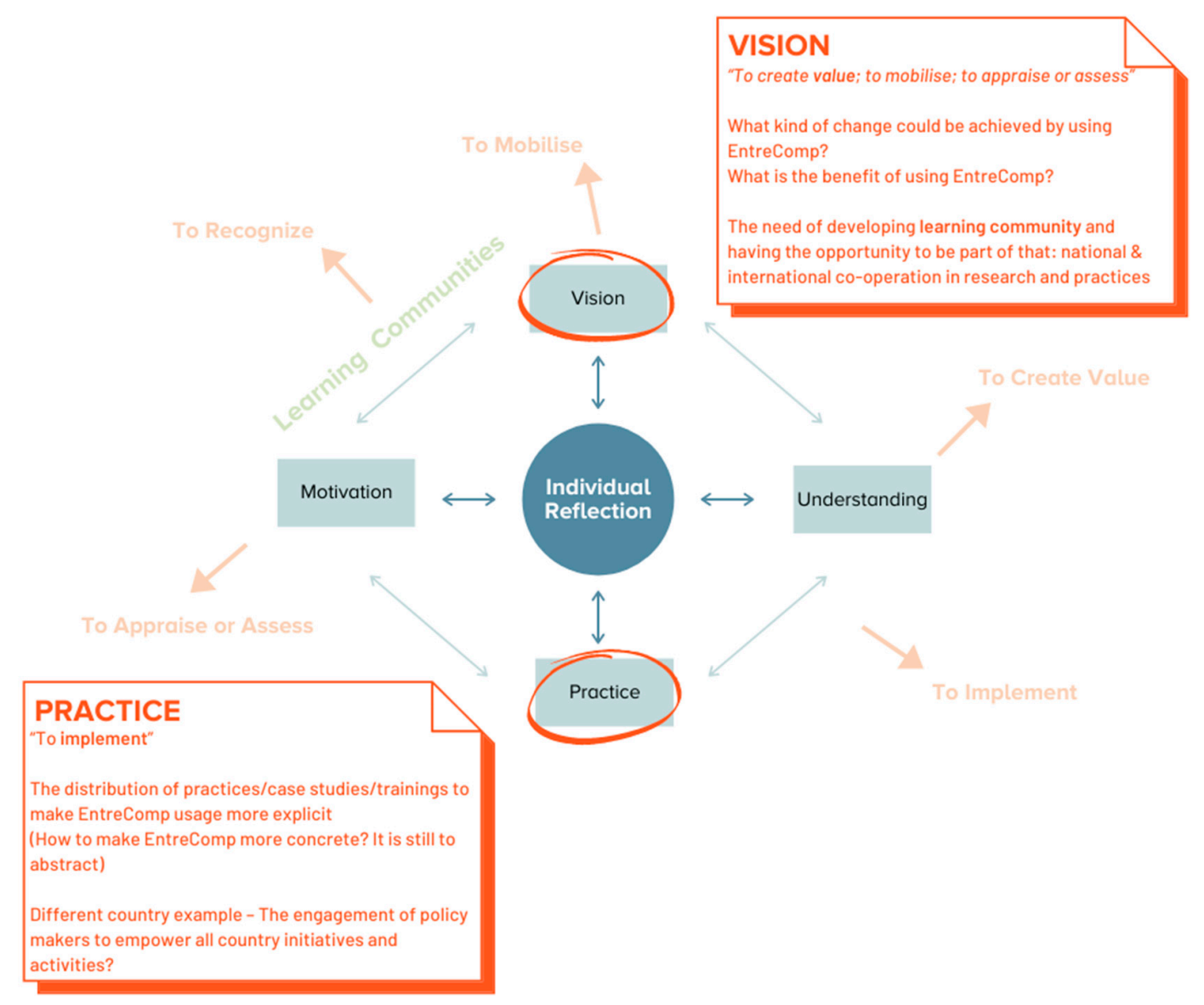

Figure 7. EntreComp as an engine for transnational policy implementation driving entrepreneurial competencies.

The results highlight that the European competence framework EntreComp can increase motivation and understanding of entrepreneurship education in different transnational contexts. Moreover, implementation has used all five goals. However, recognition of and support for learners' (e.g., educators, other practitioners, policymakers, and stakeholders) roles within various learning communities, require further study. Educational practices (e.g., training, tools, and concepts) need to be developed to support the reflection and learning of learners to empower development of their vision and practices related to entrepreneurship education. Some practical examples to promote these are presented in Figure 7 (e.g., case studies, other explicit models, country-specific examples, vision development through questions, and emphasis on learning communities). Further studies are still needed to identify the gaps in terms of required leverage towards coherent education change that promote entrepreneurial competences and the overall understanding of the EE within Europe. This would also provide new avenues to investigate how sustainable development could be promoted at the global, country, and local levels of education. This would also generate new knowledge on how to promote sustainable development within the private sector, for example in staff training.

Our case study has also broadened the general understanding of the way in which European strategies are guiding the development of entrepreneurial education. Overall, this kind of case study provides a suitable platform for investigating how these global goals can be detected in individual members' attitudes and beliefs in different country 
contexts. As Cohen et al. [27] argues, the generalizability of such single experiments (e.g., case and pilot studies) can be further extended through replication or multiple experiment strategies, which allows single case studies to contribute to the development of a growing pool of data for eventually achieving a wider generalizability of the key findings. Therefore, we suggest similar types of studies to be conducted to identify how policy goals can be successfully translated into frameworks, and what are the best practices for their successful implementation. Furthermore, a series of large-scale international studies could be useful in detecting how entrepreneurial education can be driven through policy framework, but also in demonstrating the added value of entrepreneurship education, as an example, by evaluation and case studies that would emphasize the learning and reflection processes within and across learning communities. This would also enable the design of more practical concepts and tools to support community learning processes to further strengthen entrepreneurial competences.

However, our research has certain limitations that need to be considered. For example, the number of respondents differed to some extent in different countries. Although the measure utilized previous bases, it could be further developed and validated based on the theoretical basis of Shulman and Shulman [14], and Seikkula-Leino [26], and SeikkulaLeino et al. [21,50,51]. In addition, we could further develop the metrics to guide the target group to respond more precisely to issues related to sustainable development.

Undoubtedly, our research has significant value in finding out how, in practice, the European framework promotes practical change in teaching and learning. We highlight concrete proposals that could be considered in the future. In addition, we have opened up the theoretical discussion of entrepreneurship education in the direction of education science by utilizing the results obtained in this field and theoretical entry angles by stressing learning communities and their reflection. With this research, we contribute to the development of entrepreneurship education in many ways, both in theory and in practice, and globally, thus providing a sustainable ground for developing entrepreneurial society by education.

Author Contributions: Conceptualization, J.S.-L. and E.M.; methodology, J.S.-L.; formal analysis, J.S.-L., M.S., S.R.J., E.M., and H.I.;- original draft preparation, J.S.-L., M.S., S.R.J., E.M., and H.I.; writing-review and editing, J.S.-L., M.S., S.R.J., E.M., and H.I.; visualization, E.M. All authors have read and agreed to the published version of the manuscript.

Funding: The investigative process and data findings supporting this research paper were funded through the EntreComp360 project co-financed through the Erasmus+ programme of the European Union.

Institutional Review Board Statement: Not applicable.

Informed Consent Statement: Not applicable.

Data Availability Statement: The dataset generated for this study will not be made publicly available because of the sensitive nature of the questions. All study participants were assured that the data will remain confidential and will not be shared. All requests concerning the access to the dataset should be directed to the corresponding author.

Conflicts of Interest: The authors declare no conflict of interest.

\section{References}

1. United Nations. Transforming Our World: The 2030 Agenda for Sustainable Development. 2015. Available online: https://sdgs. un.org/sites/default/files/publications/21252030\%20Agenda\%20for\%20Sustainable\%20Development\%20web.pdf (accessed on 10 February 2021).

2. European Commission. European Skills Agenda for Sustainable Competitiveness, Social Fairness and Resilience. 2020. Available online: https: / / ec.europa.eu/social/BlobServlet?docId=22832\&langId=en (accessed on 5 February 2021).

3. Bacigalupo, M.; Kampylis, P.; McCallum, E.; Punie, Y. Promoting the Entrepreneurship Competence of Young Adults in Europe: Towards a Self-Assessment Tool. In Proceedings of the 9th International Conference of Education, Research and Innovation, Seville, Spain, 14-16 November 2016; pp. 611-621. [CrossRef] 
4. European Commission. Green Paper “Entrepreneurship in Europe”. 2003. Available online: https://eur-lex.europa.eu/legalcontent/EN/TXT/PDF/?uri=CELEX:52003DC0027\&from=EN (accessed on 12 December 2020).

5. Borbás, L. A critical analysis of the 'Small Business Act' for Europe. In Proceedings of the 7th International Conference on Management, Enterprise and Benchmarking, Budapest, Hungary, 5-6 June 2009.

6. Dinning, T. Articulating entrepreneurial competencies in the undergraduate curricular. ET 2019, 61, 432-444. [CrossRef]

7. Garbutt, J.; Antes, A.; Mozersky, J.; Pearson, J.; Grailer, J.; Toker, E.; DuBois, J. Validating curricular competencies in innovation and entrepreneurship for biomedical research trainees: A modified Delphi approach. J. Clin. Transl. Sci. 2019, 3, 165-183. [CrossRef] [PubMed]

8. Joint Research Centre. EntreComp: The Entrepreneurship Competence Framework; Publications Office of the European Union: Luxembourg, 2016; Available online: https:/ / data.europa.eu/doi/10.2791/593884 (accessed on 25 May 2021).

9. Weicht, R.; Ivanova, I.; Gikopoulou, O. The CRADLE teaching methodology: Developing foreign language and entrepreneurial skills in primary school pupils. Entrep. Educ. 2020, 3, 265-285. [CrossRef]

10. Jónsdóttir, S.R. Entrepreneurship Education at the Upper-Secondary Level in ICELAND in 2020. Available online: https: / / entrecomp360.eu/entrepreneurship-education-upper-secondary-level-iceland-2020/ (accessed on 12 June 2021).

11. Teneva, I. Entrepreneurial Competences: Comparison of Proacademy and EntreComp. Tampereen Ammattikorkeakoulu, 2018. Available online: https:/ /www.theseus.fi/handle/10024/158476?show=full (accessed on 7 October 2020).

12. Education, Audiovisual and Culture Executive Agency. Entrepreneurship Education at School in Europe: Eurydice Report; Publications Office of the European Union: Luxembourg, 2016; Available online: https:/ / data.europa.eu/doi/10.2797/731298 (accessed on 25 May 2021).

13. Ruskovaara, E.; Pihkala, T.; Seikkula-Leino, J.; Järvinen, M.R. Broadening the resource base for entrepreneurship education through teachers' networking activities. Teach. Teach. Educ. 2015, 47, 62-70. [CrossRef]

14. Shulman, L.S.; Shulman, J.H. How and what teachers learn: A shifting perspective. J. Curric. Stud. 2004, 36, 257-271. [CrossRef]

15. Seikkula-Leino, J. Developing entrepreneurship education in Europe: Teachers' commitment to entrepreneurship education in the UK, Finland and Spain. In The Role and Impact of Entrepreneurship Education; Edward Elgar Publishing: Cheltenham, UK, 2019; pp. 130-145. [CrossRef]

16. Kelchtermans, G. Teachers' emotions in educational reforms: Self-understanding, vulnerable commitment and micropolitical literacy. Teach. Teach. Educ. 2005, 21, 995-1006. [CrossRef]

17. Cooper, S.; Bottomley, C.; Gordon, J. Stepping Out of the Classroom and up the Ladder of Learning: An Experiential Learning Approach to Entrepreneurship Education. Ind. High. Educ. 2004, 18, 11-22. [CrossRef]

18. Fayolle, A.; Gailly, B. From craft to science: Teaching models and learning processes in entrepreneurship education. J. Eur. Ind. Train. 2008, 32, 569-593. [CrossRef]

19. Henderson, R.; Robertson, M. Who wants to be an entrepreneur? Young adult attitudes to entrepreneurship as a career. Educ. Train. 1999, 41, 236-245. [CrossRef]

20. Pittaway, L.; Cope, J. Simulating Entrepreneurial Learning: Integrating Experiential and Collaborative Approaches to Learning. Manag. Learn. 2007, 38, 211-233. [CrossRef]

21. Seikkula-Leino, J.; Ruskovaara, E.; Hannula, H.; Saarivirta, T. Facing the Changing Demands of Europe: Integrating Entrepreneurship Education in Finnish Teacher Training Curricula. Eur. Educ. Res. J. 2012, 11, 382-399. [CrossRef]

22. Pittaway, L.; Hannon, P. Institutional strategies for developing enterprise education: A review of some concepts and models. J. Small Bus Ente. Dev. 2008, 15, 202-226. [CrossRef]

23. Jónsdóttir, S.R.; Macdonald, M.A. The feasibility of innovation and entrepreneurial education in middle schools. JSBED 2019, 26, 255-272. [CrossRef]

24. Hannay, L.M.; Earl, L. School district triggers for reconstructing professional knowledge. J. Educ. Change 2012, 13, 311-326. [CrossRef]

25. Perrotta, C. Beyond rational choice: How teacher engagement with technology is mediated by culture and emotions. Educ. Inf. Technol. 2017, 22, 789-804. [CrossRef]

26. Seikkula-Leino, J. The implementation of entrepreneurship education through curriculum reform in Finnish comprehensive schools. J. Curric. Stud. 2011, 43, 69-85. [CrossRef]

27. Cohen, L.; Manion, L.; Morrison, K. Research Methods in Education, 8th ed.; Routledge: New York, NY, USA; London, UK, 2018.

28. EntreComp360 Project Online. Available online: https:/ / entrecomp360.eu/ (accessed on 6 October 2020).

29. Mccallum, E.; Weicht, R.; Mcmullan, L.; Price, A. EntreComp into Action-Get Inspired, Make it Happen: A User Guide to the European Entrepreneurship Competence Framework; Bacigalupo, M., O'keeffe, W., Eds.; Publications Office of the European Union: Luxembourg, 2018; Available online: https:/ / data.europa.eu/doi/10.2760/574864 (accessed on 25 May 2021).

30. Šlaus, I.; Jacobs, G. Human Capital and Sustainability. Sustainability 2011, 3, 97-154. [CrossRef]

31. Torfi Jónasson, J. Policy and reality in educational development: An analysis based on examples from Iceland. J. Educ. Policy 2002, 17, 659-671. [CrossRef]

32. Jónsdóttir, S.R.; Gunnarsdóttir, R. The Road to Independence: Emancipatory Pedagogy. 2017. Available online: https://doi.org/ 10.1007/978-94-6300-800-6 (accessed on 25 May 2021). 
33. Jónsdóttir, S.R.; MacDonald, A. Settings and Pedagogy in Innovation Education. In The Routledge International Handbook of Innovation Education; Shavinina, L.V., Ed.; Routledge: Abingdon, UK, 2013; pp. 273-287. Available online: http:/ / site.ebrary.com/ id/10691776 (accessed on 25 May 2021).

34. European Commission. Effects and Impact of Entrepreneurship Programmes in Higher Education. 2012. Available online: https: / / ec.europa.eu/docsroom/documents/375/attachments/1/translations/en/renditions/native (accessed on 20 January 2021).

35. Smyth, J. Schooling and enterprise culture: Pause for a critical policy analysis. J. Educ. Policy 1999, 14, 435-444. [CrossRef]

36. Sukarieh, M.; Tannock, S. Putting school commercialism in context: A global history of Junior Achievement Worldwide. J. Educ. Policy 2009, 24, 769-786. [CrossRef]

37. Mccallum, E.; Mcmullan, L.; Weicht, R.; Kluzer, S. EntreComp at Work; Bacigalupo, M., Ed.; Publications Office of the European Union: Luxembourg, 2020; Available online: https:/ / data.europa.eu/doi/10.2760/673856 (accessed on 25 May 2021).

38. Patton, K.; Parker, M. Teacher education communities of practice: More than a culture of collaboration. Teach. Teach. Educ. 2017, 67, 351-360. [CrossRef]

39. Wenger-Trayner, E.; Fenton-O'Creevy, M.; Hutchinson, S.; Kubiak, C.; Wenger-Trayner, B. Learning in Landscapes of Practice: Boundaries, Identity, and Knowledgeability in Practice-Based Learning; Routledge: London, UK; New York, NY, USA, 2015.

40. Lave, J.; Wenger, E. Situated Learning: Legitimate Peripheral Participation, 1st ed.; Cambridge University Press: Cambridge, UK, 1991. [CrossRef]

41. Chaurasia, S.S.; Kaul, N.; Yadav, B.; Shukla, D. Open innovation for sustainability through creating shared value-role of knowledge management system, openness and organizational structure. JKM 2020, 24, 2491-2511. [CrossRef]

42. Ibrahim, M. The use of community based learning in educating college students in Midwestern USA. Procedia Soc. Behav. Sci. 2010, 2, 392-396. [CrossRef]

43. Chung, E.Y. Facilitating learning of community-based rehabilitation through problem-based learning in higher education. BMC Med. Educ. 2019, 19, 433. [CrossRef]

44. Lundy, B.L. Service Learning in Life-Span Developmental Psychology: Higher Exam Scores and Increased Empathy. Teach. Psychol. 2007, 34, 23-27. [CrossRef]

45. Ngai, S.S.-y. Service-learning, personal development, and social commitment: A case study of university students in Hong Kong. Adolescence 2006, 41, 165-176. [PubMed]

46. Phan, M.-H.; Ngo, H.Q.T. A Multidisciplinary Mechatronics Program: From Project-Based Learning to a Community-Based Approach on an Open Platform. Electronics 2020, 9, 954. [CrossRef]

47. Sather, P.; Weitz, B.; Carlson, P. Engaging Students in Macro Issues through Community-Based Learning: The Policy, Practice, and Research Sequence. J. Teach. Soc. Work 2007, 27, 61-79. [CrossRef]

48. Joseph, C.; Said, R. Community-Based Education: A Participatory Approach to Achieve the Sustainable Development Goal. In Quality Education; Leal Filho, W., Azul, A.M., Brandli, L., Özuyar, P.G., Wall, T., Eds.; Springer International Publishing: Cham, Switzerland, 2020; pp. 101-111. [CrossRef]

49. Community-based learning for sustainable development. UNESCO Institute for Lifelong Learning. 2017. Available online: https: / / unesdoc.unesco.org/ark:/48223/pf0000247569 (accessed on 8 August 2020).

50. Seikkula-Leino, J.; Ruskovaara, E.; Ikavalko, M.; Mattila, J.; Rytkola, T. Promoting entrepreneurship education: The role of the teacher? Educ. Train. 2010, 52, 117-127. [CrossRef]

51. Seikkula-Leino, J.; Ruskovaara, E.; Ikävalko, M.; Kolhinen, J.; Rytkölä, T. Teachers' Reflections on Entrepreneurship Education: Their Understanding and Practices. In Conceptual Richness and Methodological Diversity in Entrepreneurship Research; Fayolle, A., Kyrö, P., Mets, T., Venesaar, U., Eds.; Edward Elgar: Cheltenham, UK; Northampton, MA, USA, 2013; pp. $146-171$.

52. Yin, R.K. Case Study Research: Design and Methods, 5th ed.; SAGE: Los Angeles, CA, USA, 2014.

53. Ruskovaara, E.; Pihkala, T.; Seikkula-Leino, J.; Rytkölä, T. Creating a measurement tool for entrepreneurship education: A participatory development approach. In Developing, Shaping and Growing Entrepreneurship; Edward Elgar Publishing: Cheltenham, UK, 2015; pp. 40-59. [CrossRef]

54. Hynes, B.; Richardson, I. Entrepreneurship education: A mechanism for engaging and exchanging with the small business sector. Educ. Train. 2007, 49, 732-744. [CrossRef]

55. Deveci, İ.; Seikkula-Leino, J. A Review of Entrepreneurship Education in Teacher Education. MJLI 2018, 15, 105-148. [CrossRef] 